\title{
Milestones and legal devices to combat violence against women in Brazil
}

\author{
Marcos e dispositivos legais no combate à violência contra a mulher no Brasil \\ Marcos y dispositivos legales para combatir la violencia contra la mujer en Brasil \\ Larissa Alves de Araújo Lima*; Claudete Ferreira de Souza Monteiro**; \\ Fernando José Guedes da Silva Júnior ${ }^{* * *}$; Andrea Vieira Magalhães Costa ${ }^{* * * *}$
}

\begin{abstract}
Background: Violence against women is the result of a pattern of aggressive behaviors that cause physical, psychological, moral, material, and sexual harm.

Objectives: To discuss the historical evolution of the milestones and legal devices to combat violence against women in Brazil.

Main topics under analysis: The milestones and legal devices to combat violence against Brazilian woman include an apparatus of laws, ministerial programs, agreements, ordinances, and the creation of specialized police stations. They are based on the Federal Constitution of 1988, the high rates of violence against women, and the country's ratification of international conventions.

Conclusion: History shows that milestones and legal devices have been and still are important for the visibility, awareness, and community and academic discussion of the problem. However, it is important to recognize that violence against woman continues to be a public health issue.
\end{abstract}

Keywords: violence against woman; politics; women's health

\section{Resumo}

Enquadramento: A violência contra a mulher é resultado de comportamentos agressivos que causam dano físico, psicológico, moral, patrimonial e sexual.

Objetivos: Discutir a evolução histórica dos marcos e dispositivos no combate à violência contra a mulher no Brasil.

Principais tópicos em análise: Os marcos e dispositivos legais para o combate à violência contra a mulher emolduram diversas leis, programas ministeriais, pactos, portarias, criação de delegacias especializadas. Têm por base a Constituição Federal de 1988, elevadas taxas de violência contra a mulher e a participação do país em convenções internacionais, das quais o Brasil é signatário. Conclusão: O caminho histórico mostra que os marcos e dispositivos legais foram e continuam a ser importantes para visibilidade do problema, consciencialização e discussão comunitária e académica. Porém, torna-se necessário reconhecer que a violência contra a mulher é, ainda, um agravo de saúde pública.

Palavras-chave: violência contra a mulher; políticas públicas; saúde da mulher

\footnotetext{
* MSc., RN, Master's student in Nursing, Federal University of Piauí, 64.049-550, BraZil [larissaalves_@ hotmail.com]. Address for correspondence: Rua Beneditinos, $\mathrm{n}^{0}$ 656, Teresina, 64.049-550, Brasil [larissaalves_@ hotmail.com]. Contribution to the article: data collection and treatment, article writing. ** Ph.D., RN, Teacher of the Postgraduate Degree in Nursing, Federal University of Piauí, 64.0499-550, Brazil

[claudetefmonteiro@ hotmail.com]. Contribution to the article: data analysis and discussion.
${ }_{*}^{*} * *$ MSc., RN, PhD Student of the Postgraduate Nursing Programme, Federal University of Piauí, Teache of the Degree in Nursing, Federal University of Piauí, 64.049-550, Brazil [fernandoguedesir@gmail.com]

Contribution to the article: data analysis and discussion.
${ }_{* * * * *}^{*}$ MSc., RN, Master's student in Family Health, Federal University of Piaú, 64.049-550, Brazil [andreavieira_mc@hotmail.com].Contribution to the article: data analysis and discussion.
}

\section{Resumen}

Marco contextual: La violencia contra la mujer es el resultado de un patrón de conducta agresiva que causa daño físico, psicológico, moral, patrimonial y sexual.

Objetivo: Analizar el desarrollo histórico de los marcos y dispositivos para el tratamiento de la violencia contra la mujer en Brasil.

Principales temas en análisis: Los marcos y dispositivos legales para combatir la violencia a la mujer brasileña engloban un aparato de leyes, programas ministeriales, acuerdos, entrenamiento de la red, ordenanzas, creación de comisarías especializadas. Se basan en la Constitución Federal de 1988, las altas tasas de violencia contra la mujer y la participación de Brasil en los convenios internacionales, de cuyas decisiones es signatario.

Conclusión: La ruta histórica muestra que los marcos y dispositivos legales han sido y siguen siendo importantes para la visibilidad del problema, la sensibilización y la discusión comunitaria y académica. Sin embargo, es necesario reconocer que la violencia contra la mujer sigue siendo un delito a la salud pública.

Palabras clave: violencia contra la mujer; políticas públicas; salud de la mujer

Received for publication: 19.04 .16 Accepted for publication: 28.10.16 


\section{Introduction}

Violence against women is a major public health issue. Historically, this type of violence is the product of the close relationship between the categories of gender, class, race/ethnicity, and their power relations. This term is used since the 1950s, but it has only recently become a health focus and influenced the creation of intervention policies and social initiatives, both nationally and internationally. The victims of violence against women show a higher social vulnerability, post-traumatic stress, and depression, and can even become suicidal (Michau, Horn, Bank, Dutt, \& Zimmerman, 2015). Violence against women is the result of a pattern of aggressive behaviors that may involve punching, kicking, use of weapons, humiliation, threats, sexual acts against the victim's will, and financial abuse in which the abuser controls the partner's finances so as to make her dependent (White \& Satyen, 2015).

The United Nations (UN) began its efforts to fight against this form of violence with the creation of the Commission on the Status of Women which produced, between 1949 and 1962, a series of documents on the rights that should be equally applied to men and women, without any kind of distinction. In addition, several actions, policies, milestones, and legal devices were developed with a view to implementing preventive and protective measures for women, as well as to promote their empowerment (Pinafi, 2012). Despite the advancements and achievements, studies conducted in Brazil show that the prevalence of intimate partner violence against women is still quite high. A study conducted in the state of São Paulo, southern region of Brazil, with 2,379 women, found that $55.7 \%$ of them were victims of violence perpetrated by an intimate partner (Mathias, Bedone, Osis, \& Fernandes, 2013). Another study, conducted in the northeast region of the state of Paraiba, with a sample of 86 women, found that $63 \%$ of the women had been victims of violence, and that $39 \%$ of violent episodes had been perpetrated by their partner (Albuquerque et al., 2013).

This type of violence is culturally, socially and historically influenced. Therefore, it is important to study the milestones and legal devices for combating violence against women, since, by analyzing the existing knowledge and reflections on this topic, it is possible to find contributions to redirect policies and increase the discussion within the community, inviting it also to reflect on these events, their effects and improvements. The objective of this study is to discuss the historical evolution of the milestones and legal devices for combating violence against women in Brazil.

To develop this study, we conducted a reflective analysis of the milestones and legal devices for combating violence against women in Brazil. A literature review was previously conducted to obtain a more comprehensive analysis.

The literature review was performed between July and August 2015, using the following keywords: violência contra a mulher (violence against women); políticas públicas (public policies); saúde da mulher (women's health); violência de género (gender-based violence). The inclusion criteria were: addressing the topic, articles, legislation, books and collections published by national secretariats. Booklets and documents that did not address the topic were excluded. The articles were searched in the databases of the Latin American and Caribbean Center on Health Sciences Information (LILACS) and the Scientific Electronic Library Online (SciELO), and in the Brazilian Federal Government official websites.

\section{Development}

Violence against women happens in all countries, races, and cultures. This is because this type of violence is rooted in discrimination, in the view that women are fragile and submissive to men (MacDonald, 2013). Throughout history, this problem was masked by society and interpreted as a family situation, which could only be solved within the family.

Men have always embraced politics, the power of choice, the right to work, to behave freely in society, while women should only have jobs related to sewing and cooking, which led to relationships of dominance, violence and violation of women's human rights (Santos \& Marques, 2014). Women became aware of these situations of inequality, and started searching for other social roles, the right to develop a professional activity and engage in politics, among others. The results that will be presented here date back to key events in Brazil between 1981 and 2015 that contributed to combating violence against women. 
However, some international events, which mark the presence of women in new contexts, should be addressed, namely the French Revolution, which is a political and ideological milestone for the Western world, empowering women to claim and set a new status in society. Women have sought different roles beyond caring for the home and the children and being a submissive wife, and have fought for a position as citizens and workers. This movement, which was already visible in the $19^{\text {th }}$ century, marks the trajectory of the feminist struggles (Oliveira, 2012). Although a necessity of that particular context, it marked the beginning of the first feminist struggles for spaces that women could occupy outside the private sphere.

Another historical moment is an incident that took place in New York, United States, on 8 March 1857, when the female workers of a textile factory organized a strike for better working conditions, workload reduction, and gender equality in salaries. However, the factory was set on fire with the women locked inside and approximately 130 female workers died. In tribute to this group, in 1910, during a conference in Denmark, the 8th of March was set to be the International Women's Day. It was only in 1975 that the date was made official by the UN (Pinafi, 2012).

Still at the international level, after years of women's struggles, the UN created the Commission on the Status of Women (CSW) in 1946 with the purpose of promoting women's rights in the political, social, and educational domains. In 1979, the Convention on the Elimination of All Forms of Discrimination against
Women (CEDAW) took place, having been approved by the General Assembly of the United Nations. This Convention was a result of the international feminist movement aimed at condemning all forms of discrimination against women (Santos \& Marques, 2014).

Violence against women took the stage in Brazil in 1981, when the country ratified the CEDAW and become more effectively involved in the defense of women's rights. Brazil was facing many problems related to women's health, including maternal mortality, unwanted pregnancy, abortion, and sexually transmitted diseases (STDs). In 1983, with the purpose of addressing these issues, the Brazilian Ministry of Health created the Program of Comprehensive Assistance to Women's Health (Programa de Assistência Integral à Saúde da Mulher, PAISM), which represents a milestone for women's health. However, this program focused only on women's reproductive health (Ramalho, Silva, Lima, \& Santos, 2012).

In 1985, the National Council on Women's Rights (Conselho Nacional dos Direitos da Mulher, CNDM) and the first Specialized Police Precinct to Assist Women (Delegacia Especializada de Atendimento à Mulher, DEAM) were founded in Brazil. Despite their importance, Brazil looked at this issue only from the justice and public safety perspective (Santos \& Marques, 2014). Since then, several mechanisms have been created to strengthen policies for combating violence against women, as can be seen in Figure 1. 


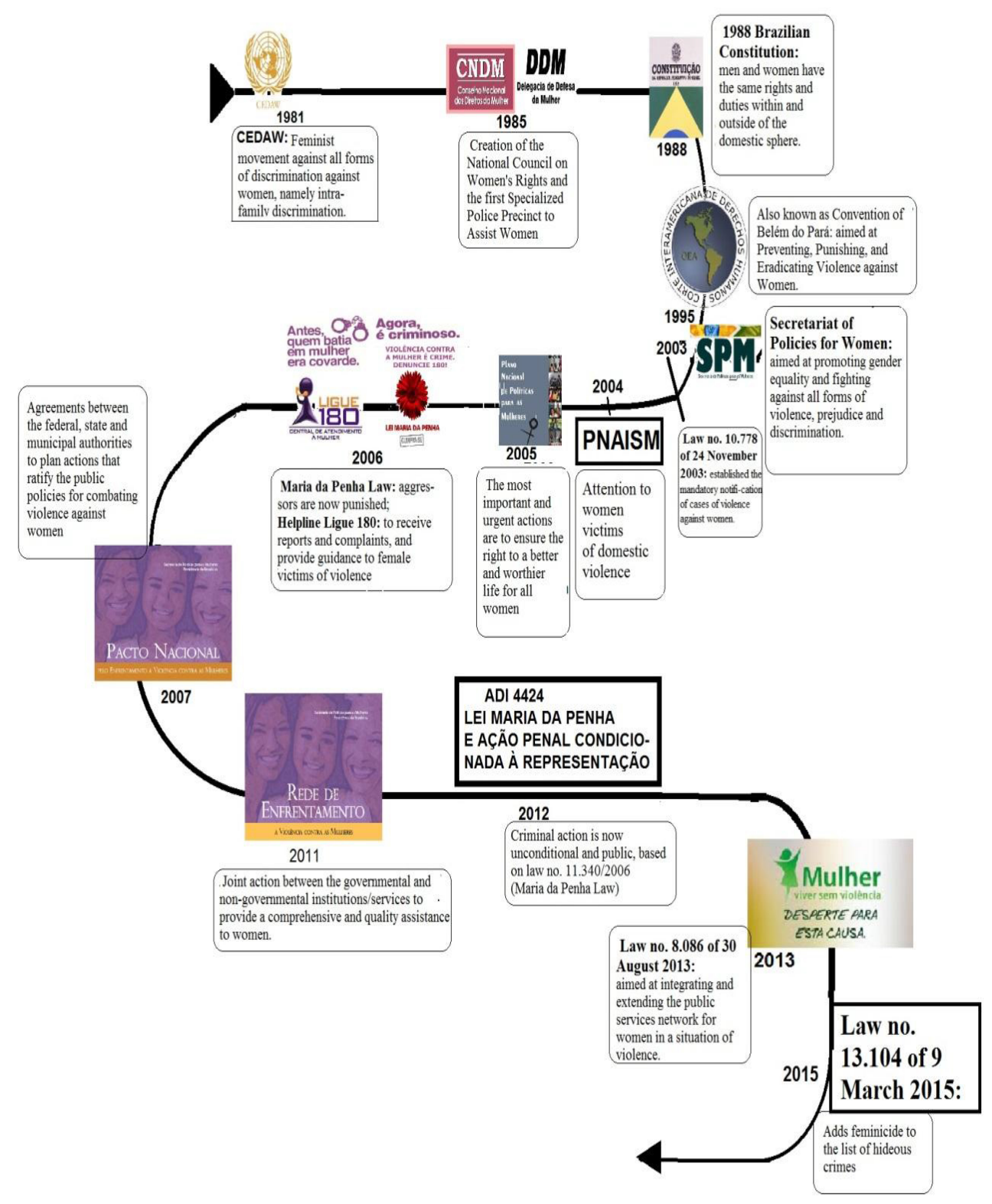

Figure 1. Timeline of the milestones and legal devices for combating violence against women in Brazil between 1981 and 2015.

With the enactment of the 1988 Federal Constitution, the social role of Brazilian women changed, and, for example, the word citizen, which made only reference to men, began to include women and new fundamental rights, such as the right to life, equality, non-discrimination, safety and property, in order to enable gender equality (Santos, 2014). However, this was not enough to allow for the change in the culture and the way in which women were seen and treated in society, especially by their partners, who continued to perpetrate acts of violence against their wives.
In 1995, Brazil ratified the Convention of Belém do Pará - the Inter-American Convention. This treaty was signed by the American countries, with the purpose of preventing, punishing and eradicating violence against women. Its Chapter II included articles that allowed women the right to freedom and equality (Pinafi, 2012). The objectives were triumphant, but little attention was given to this treaty, and it was only in 2003 that the Brazilian government created the Secretariat of Policies for Women (Secretaria de Políticas para Mulheres, SPM), on 28 May 2003. 
This secretariat aimed to promote gender equality and fight against all forms of violence, prejudice and discrimination and operated in three main areas: policies for women's labor and economic autonomy; combating violence against women; and programs and actions in the areas of health, education, culture, political participation, gender equality, and diversity (Lei $n^{0} 10.863$ of 28 May 2003). The SPM is a major milestone for combating violence against women, because it proved to be more effective in creating policies, holding events, and developing preventive measures up to the present day.

With the increasing demand of services for women victims of violence, on 24 November 2003, the Brazilian government endorsed Lei $n^{0} 10.778$ making it compulsory to report all cases of violence against women assisted in public or private health services within the national territory (Lei $\mathrm{n}^{0} 10.788$, of 24 November 2003). From then on, violence against women was considered a public health issue, due to the physical, sexual or psychological harm caused to women.

In 2004, with the support of the SPM, the National Policy for Women's Comprehensive Health Care (Política Nacional de Atenção Integral à Saúde da Mulher, PNAISM) was created. This Policy was based on PAISM, but had a broader scope, focusing on gender issues, comprehensive care and health promotion, the inclusion of sexual and reproductive rights, assistance in family planning, unsafe abortion and the fight against domestic and sexual violence as guiding principles, the latter being one of the main indicators of gender discrimination against women. This was another important milestone to combat violence against women, since this was the first policy on women's care to emphasize this issue and adopt a more humanized approach (Ramalho et al., 2012). In addition, the SPM held the First National Conference on Policies for Women (I Conferência Nacional de Policias para Mulberes, CNPM) in July 2004, bringing together around 120,000 women who, after several debates, presented their proposals for the development of the National Plan for Women's Policies (Plano Nacional de Políticas para as Mulberes, PNPM). We would like to underline that conferences are important for women's political inclusion, since they are the ones discussing the issues at the conferences and deciding the best way to formulate policies. A study conducted in Belo
Horizonte, however, claims that the resolutions adopted at conferences have no systematic impact on public policies (Brasil \& Reis, 2015).

In 2005, the PNPM was designed based on the following key points: equality and respect for diversity, equality and empowerment of women, universality of policies, secular state, social justice, transparency of public administration, and social participation and monitoring. The priority actions of the plan were organized into four lines of action: autonomy, equality in society, labor and citizenship, inclusive and non-sexist education, women's health, sexual and reproductive rights, and combat violence against women. These lines of action were considered to be the top priorities to ensure the right to a better and worthier life to all women (Osis, Pádua, \& Faúndes, 2013).

The Lei $n^{0} 11.340$ - the Maria da Penha Law - of 7 August 2006 was the legal device with the greatest impact on combating violence against women. This law created mechanisms to prevent domestic and family violence against women, namely the punishment of perpetrators and the creation of courts dedicated to the domestic and family violence against women. This Law also changed the Code of Criminal Procedure, the Penal Code and the Law of Penal Execution, and created shelters for women in a situation of risk or domestic violence (Lei $n^{0} 11.340$ of 7 August 2006). It should be noted that this legal device was of utmost importance, since people gained more respect for women's rights and men started fearing punishment. However, despite the advances, these mechanisms were not enough to eradicate the violence against women.

In 2006, to reinforce the Maria da Penha Law, the SPM created the women's helpline Central de Atendimento à Mulber - Ligue 180 with the purpose of receiving denounces or reports of violence and complaints about the network services, as well as providing guidance to women on their rights and applicable legislation, referring them to other services when necessary. This service enabled a more homogeneous implementation of the Maria da Penha Law, bringing the services closer to women, especially those who preferred anonymity.

In addition to the initiatives to fight violence against women, the Second CNPM was held in 2007. Here, the National Pact for Ending Violence against Women (Pacto Nacional pelo Enfrentamento à Violência 
contra a Mulher) was launched as part of the Social Agenda of the Federal Government. This pact consisted of an agreement between the Brazilian federal, state and municipal authorities with the purpose of planning actions to ratify public policies focused on fighting violence against women. This pact increased the dissemination of information in the media, promoting the prevention and reporting of cases, as women began to have greater control over their rights (Gomes, Bomfim, Diniz, Souza, \& Couto, 2012).

As a means of expanding and integrating all of these mechanisms, in 2011, the SPM created the Network for Ending Violence against Women (Rede de Enfrentamento à Violência contra a Mulher). This network consists of a joint collaboration between governmental and non-governmental institutions/ services with the purpose of developing effective prevention strategies and policies to ensure women's empowerment and rights, as well as the accountability of perpetrators and the qualified assistance to women victims of violence.

This was a key milestone, since primary health care services, police, social workers or others could not, by themselves, cover all the cases. As a result of networking, women's care becomes a shared responsibility and an interconnected system through reference and counter-reference mechanisms.

Taking into account this new focus of networking, the Third CNPM, held on 13-15 September 2011, put forward the following goals for the upcoming years: to reform and build specialized services for women in a situation of violence; to train professionals in the areas of public safety, health, education, social work, justice and other areas of the care network; and to increase the number of call centers of the helpline Ligue 180, among other important government actions toward the achievement of the population's wishes (Brasil et al., 2015). It should be noted that the conferences were held to fill in the existing gaps and that they were effective in their roles and definitions. In 2012, the majority of the women who reported aggressions ended up withdrawing the claim because they believed in their aggressor's repentance, although these partners kept on perpetrating violence. As a result, the public authorities took a new measure - the Direct Action of Unconstitutionality (Ação Direta de Inconstitucionalidade - ADI) no. 4424, which considered these aggressions to be a public criminal action based on Lei no 11.340, 7 August 2006 (the Maria da Penha Law). In this way, after reporting their partners for aggression, women can no longer withdraw the claim, which is then placed under the responsibility of the Public Prosecutor (Supremo Tribunal Federal, 2012).

In the following year, with the purpose of integrating and expanding the existing public services for women in a situation of violence, the House of the Brazilian Woman (Casa da Mulher Brasileira) was created. This center of combines specialized services in the areas of health, justice, social assistance and promotion of financial autonomy and was created within the Women: Living Without Violence (Mulher: Viver sem Violência) program, which came into force on 30 August 2013 by means of Law no. 8.086 (Lei $n^{0} 8.086$ de 30 de Agosto, 2013). This program had a strong impact on the effectiveness of the services, since it became possible to integrate public services related to security, justice, health, social assistance, protection, shelter and professional guidance, employment and income in all Brazilian capitals.

In 2014, the Map of Violence was published, which showed that, from 1980 to 2012, the rates of homicides targeting women had doubled from 2.3 to 4.8 per 100,000 women (Waiselfisz, 2014). As a result, there was a need to create a specific law to fight against feminicide, which is a severe form of violence against women. On 9 March 2015, Law no. 13.104 was enacted, considering feminicide to be an aggravated type of homicide, and including it in the list of hideous crimes (Lei 13.104/ 2015 de 09 de Março). The major benefit of this law was to increase the visibility of feminicide and allow for the most severe punishment to those who committed this crime against life.

\section{Conclusion}

Violence against women is a major public health issue, since it is an old, multifactorial process that leads to social, political, economic, and health problems.

Over the years, violence stopped being seen as a normal reality of the family situation, and began to occupy a prominent place in the development of policies and laws for its prevention and eradication. The importance of an open debate within the society, such as the organization of conferences, should also be emphasized, as they strongly contribute to the 
implementation of significant policies for women victims of violence.

We observed that the most socially relevant milestone was the Maria da Penha Law, since the issue of violence became more visible and women were encouraged to report situations of violence. The helpline Ligue 180 and the Women: Living Without Violence program should also be highlighted, as they allow greater privacy for women who file a complaint, as well as their access to information and integrated support from the network.

In view of the milestones and legal devices presented here, we observed that the Federal Government has made efforts to provide information, shelter and assistance to women victims of violence, as well as to punish the aggressors. We also believe that studies such as this should be developed to reflect on the importance, progress and achievements of women's empowerment. However, we must recognize that violence against women continues to be a public health issue with the need for a contextual analysis of the culture, education and possible causes among this population so that we can identify specific strategies for each location. Further studies should be conducted on the profile and characteristics of the aggressors, the victims and the relationships between them, in order to inform the development of new measures to fight violence.

\section{Acknowledgments}

The authors would like to thank the Brazilian Council for Scientific and Technological Development (Conselho Nacional de Desenvolvimento Científico e Tecnológico, CNPq) for funding the study entitled "Violence, alcohol and drug consumption in the female universe: prevalence, risk factors and consequences on mental health" developed by the Study Group on Nursing, Violence and Mental Health.

\section{References}

Albuquerque, J. B., César, E. S., Silva, V. C., Espínola, L. L., Azevedo, E. B., \& Ferreira Filha, M. O. (2013). Violência doméstica: Características sociodemográficas de mulheres cadastradas em uma Unidade de Saúde da Família. Revista Eletrônica de Enfermagem, 15(2), 382-390. doi: 10.5216/ree.v15i2.18941
Brasil, F. P., \& Reis, G. G. (2015). Democracia, participação e inclusão política: Um estudo sobre as conferências de políticas para mulheres em Belo Horizonte. Revista do Serviço Público, 66(1), 7-27. doi: 10.21874/rsp.v66i1.684

Gomes, N. P., Bomfim, A. N., Diniz, N. M., Souza, S. S., \& Couto, T. M. (2012). Percepção dos profissionais da rede de serviços sobre o enfrentamento da violência contra a mulher. Revista Enfermagem UERJ, 20(2), 173-178. doi:10.12957/ reuerj.2012.4035

Lei $n^{0}$ 10.788/ 2003 de 24 de Novembro. Retrieved from http:// www.planalto.gov.br/ccivil_03/eis/2003/110.778.htm

Lei no 13.104/ 2015 de 09 de Março. Retrieved from http://www. planalto.gov.br/ccivil_03/_Ato2015-2018/2015/lei/L13104. htm

Lei $n^{0}$ 10.863/ 2003 de 28 de Maio. Retrieved from http://base. socioeco.org/docs/854780.pdf

Lei $n^{\circ} 11.340$ de 7 de Agosto de 2006. Retrieved from https:// www.planalto.gov.br/ccivil_03/_Ato2004-2006/2006/Lei/ L11340.htm

Lei no 8.086 de 30 de Agosto de 2013. Retrieved from http://www. planalto.gov.br/ccivil_03/_Ato2011-2014/2013/Decreto/ D8086.htm

MacDonald, M. (2013). Women prisoners, mental health, violence and abuse. International Journal of Law and Psychiatry, 36(3-4), 293-303. doi: 10.1016/j.ijlp.2013.04.014

Mathias, A. K., Bedone, A. J., Osis, M. J., \& Fernandes, A. M. (2013). Prevalência da violência praticada por parceiro masculino entre mulheres usuárias da rede primária de saúde do estado de São Paulo. Revista Brasileira de Ginecologia e Obstetrícia, 35(4), 185-191. doi: 10.1590/\$0100-72032013000400009

Michau, L., Horn, J., Bank, A., Dutt, M., \& Zimmerman, C. (2015). Prevention of violence against women and girls: Lessons from practice. The Lancet, 385(9978), 1672-1684. doi: 10.1016/S0140-6736(14)61797-9

Oliveira, M. A. (2012). Separações e divórcios: Elementos que fazem parte da dinâmica familiar ou elementos de "desestruturação" desta. In Reflexões sobre a sociologia aplicada a educação (p. 132). Teresina, Brasil: Fundação Universidade Estadual do Piauí.

Osis, M. J., Pádua, K. S., \& Faúndes, A. (2013). Limitações no atendimento, pelas delegacias especializadas, das mulheres que sofrem violência sexual. BIS: Boletim do Instituto de Saúde, 14(3), 320-328. Retrieved from http://periodicos.ses. sp.bvs.br/pdf/bis/v14n3/v14n3a10.pdf

Pinafi, T. (2012). Violência contra a mulher: Politicas públicas e medidas protetivas na contemporaneidade. Retrieved from http://www.historica.arquivoestado.sp.gov.br/materias/ anteriores/edicao21/materia03/texto03.pdf

Ramalho, K. S., Silva, S. T., Lima, S. M., \& Santos, M. A (2012). Política de saúde da mulher à integralidade: Efetividade ou possibilidade? Cadernos de Graduação: Ciências Humanas 
e Sociais Fits, 1(1), 11-22. Retrieved from https://periodicos. set.edu.br/index.php/fitshumanas/article/viewFile/462/198

Santos, D. T., \& Marques, A. D. (2014). A convenção sobre a eliminação de todas as formas de discriminação contra as mulheres no Brasil: Implicações nas políticas públicas voltadas às mulheres indígenas. RevistaDi@logus, 3(1). Retrieved from http://revistaeletronica.unicruz.edu.br/ index.php/Revista/article/view/1912/433

Santos, F. L. (2014). O dilema jurídico da mulher no Brasil. Sinais: Revista de Ciências Sociais, 2(1), 38-59. Retrieved from http://periodicos.ufes.br/sinais/article/view/10364/7316
Supremo Tribunal Federal. (2012). Ação Direta de Inconstitucionalidade $n^{\circ} 4.424$. Retrieved from http://redir.stf.jus.br/paginadorpub/paginador. jsp? $\mathrm{doc} T \mathrm{P}=\mathrm{TP} \& \mathrm{docID}=6393143$

Waiselfisz, J. J. (2014). Mapa da violência 2014: Os jovens do Brasil. Retrieved from http://www.mapadaviolencia.org.br/ pdf2014/Mapa2014_JovensBrasil_Preliminar.pdf

White, M. E., \& Satyen, L. (2015). Cross-cultural differences in intimate partner violence and depression: A systematic review. Aggression and Violent Behavior, 24(Sept.-Oct. 2015), 120-130. doi: 10.1016/j.avb.2015.05.005 